Journal of Finance and Banking Review

Journal homepage: www. gatrenterprise. com/GATRJournals/index. html

J. Fin. Bank. Review 3 (4) 48-53 (2018)

\title{
Conceptual Framework for the Determinants of Mutual Fund Performance in Malaysia
}

\author{
Hafinaz Hasniyanti Hassan, ${ }^{1}$ Nazimah Hussin ${ }^{2}$ \\ ${ }^{1,2}$ Azman Hashim International Business School, Universiti Teknologi Malaysia, 54100, Kuala Lumpur, Malaysia
}

\begin{abstract}
Objective -The aim of the study is to identify the determinants of mutual fund performance. Mutual funds have grown in the global financial scene since the 1890s. Past studies have examined various issues associated with mutual funds. However, in Malaysia, mutual fund related studies are rather limited. While most global researches observe the determinants of conventional mutual fund performance, the literature in Malaysia focuses only on a comparison of the performance of mutual funds. Hence, this study aims to fill that gap by providing a framework to assess the determinants of mutual fund performance. More specifically, the study proposes a conceptual framework to determine the effect of historical return, fund governance, timing and selection skills on mutual fund performance. The advancement of the study can be found through the use of theory of performance and mutual fund fees as a mediator in determining the performance of mutual fund fees.

Methodology/Technique - A quantitative approach based on secondary data will be used in this study. Multivariate regression analysis and structural equation modelling is also used to evaluate the relationship between the variables.

Findings - A conceptual framework is proposed based on the Theory of Performance. The model fit and the mediating role of mutual fund fees will be confirmed after the collection of the research data. It is expected that historical return, fund governance, timing and selection skills will affect mutual fund performance and mutual fund fees will mediate the relationship between the two.
\end{abstract}

Novelty - This study will provide a new perspective on mutual fund performance by using the Theory of Performance. In addition, the mediating role of mutual fund fees is further examined in relation to the specified determinants and mutual fund performance.

Type of Paper: Review.

Keywords: Mutual Funds; Fees; Performance; Mediator; Theory of Performance.

JEL Classification: G10, G11, G19.

\footnotetext{
* Paper Info: Received: September 18, 2018

Accepted: December 11, 2018

* Corresponding author: Hafinaz Hasniyanti Hassan

E-mail: hafinazhassan@gmail.com

Affiliation: Azman Hashim International Business School, Universiti Teknologi Malaysia, Malaysia
} 


\section{Introduction}

Mutual funds have become a vital investment for individual and institutional investors. A mutual fund refers to an asset with collective features. It brings investors with parallel goals together in a portfolio of diversified asset classes. The portfolio is managed by a qualified fund manager who will make a structured decision based on sound investment principles. Hence, the investors will benefit from the expertise and normally earn higher investment returns from both the income distribution and principal appreciation. In return, the investors will pay a fee to the fund managers for their expertise. The return to the investors is based on the performance of the mutual fund. Therefore, it is important to study the determinants of mutual fund performance as it predicts the return to the investors.

Past studies have largely focused on the determinants on mutual fund fees (Hu et al., 2016; Adam et al., 2012; Drago et al., 2010; Gilbazo et al., 2010) and examine the determinants of mutual fund performance (Matallín-Sáez et al., 2016; Philips et al., 2016; Jordan \& Riley, 2015; Hou T., 2012). However, there is presently a lack of research that simultaneously examines all of the determinants together. Moreover, mutual fund fees are essential for potential investors when considering whether to make an investment as it will reduce the amount of initial capital. Hence, this study aims to analyze the direct effect of the determinants on mutual fund performance as well as propositioning mutual fund fees as mediator on the relationship between the determinants and mutual fund performance.

\section{Literature Review and Hypothesis Development}

Finance theories have often been used to explain the relationship between the determinants and mutual fund performance: efficient market theory (Ippolito, 1989), asset pricing theory (Chen \& Knez, 1996), transaction cost theory (Williamson, 1981), and agency cost theory (Dalmácio \& Nossa, 2004). These theories have identified the relationship between the determinants and mutual fund performance. In that regard, this study uses the theory of performance. The dependent and independent variables of the study have been derived from the theory of performance. The theory of performance has previously been applied in research on the inter-disciplinary nature of performance. It is also useful in many learning contexts. The use of this theory in the present study reveals that performance is dependent on the level of knowledge, levels of skills and personal factors. Performance is also affected by cost (Elger, 2007). For this, the present study uses components and attributes of the theory of performance to determine the factors that affect mutual fund performance.

\subsection{Historical Return}

Many investors focus on historical returns as an indicator of fund performance rather than considering the underlying characteristics of the fund. Historical return reveals the operation of the fund. It relates to the level of knowledge in the Theory of Performance whereby information is acquired by experience to establish the level of performance. Historical performance and volatility of return are robust predictors of future performance and anomalous return. In short, funds with relatively high past returns tend to attract new investments (Jordan \& Riley, 2015; Chou \& Hardin, 2013; Hou, 2012; Aragon \& Ferson, 2006). Past studies have emphasized the persistent performance of mutual funds and positive relationships have been established between future and historical returns, particularly in weak performing funds. Consistent performance indicates that the historical returns of funds are expected to repeat in future. However, consistent performance is not the sole factor upon which an investor should base their decision to invest (Matallín-Sáez et al., 2016; Phillips et al., 2016; Sharma \& Paul, 2015). Ahmad et al. (2006) state that price variations arise without any significant pattern. Therefore, additional information should be considered in order for investors to make more informed investment decisions. In addition, Chou and Hardin (2013) also identified that those 
investors who pursue past performance restrict the ability of fund managers to optimize their investments. Thus, due to varied findings in previous studies, the following hypothesis is developed for this study:

H1: There is a relationship between historical return and mutual fund performance.

\subsection{Fund Governance}

Fricke (2013) states that fund governance is the controls which involve management of funds, direction and regulation. The principal subjects include board individuality, subcontracted independent assessment, segregation of roles, conflicts of interest, translucence and reporting. Mutual funds are administered by a board of directors that act on the interest of shareholders and are responsible for dealing with the fund manager. Fund governance is regarded as a personal factor in the Theory of Performance and is associated with personal situations in managing fund performance. Recent studies have considered the relationship between fund governance and mutual fund performance. Adams et al. (2016) found that team-managed mutual funds under strong fund governance structures show better performance in relation to individually managed funds. Nevertheless, Hornstein and Hounsell (2016) adopt a different view that fund performance is considerably lower when team managers co-invest in the funds compared to ones that are individually managed. Casavecchia (2016) reinforces the view that better governance in the form of stronger managerial incentive schemes signify an effective monitoring device to poor flow-performance sensitivity. Early literature (Cremers et al., 2009; Adams et al., 2010) also supports the connection between fund governance and mutual fund performance. Based on these findings, fund governance is applicable in mutual fund performance, thus:

H2: There is a relationship between fund governance and mutual fund performance.

\subsection{Timing and Selection Skills}

The timing and selection skills relate to the level of skills in establishing performance as per the Theory of Performance. Market timing skill refers to the ability to adjust market exposure at the right time while stockselection skill is the ability to choose funds with a parallel systematic risk. Investors identify fund manager skill in money management and appropriately compensate it by investing more capital in performing funds (Berk \& Van-Binsbergen, 2015). On the other hand, there is an inconsistent relationship between timing and selection skills with mutual fund performance. Sharma and Paul (2015) in their study of Indian equity mutual funds found that there is a lack of proof on superior investment skills in managing funds. In the same vein, Jordan and Riley (2015) indicate that timing and selection skills are insignificant in the relationship between fund volatility and upcoming performance. Based on these mixed findings, the following hypothesis is proposed:

H3: There is a relationship between timing and selection skills and mutual fund performance.

\subsection{Mutual Fund Fees}

Past literature has revealed a relationship between fund fees and performance. Further, the mismanagement of fees can lead to consistent negative fund performance (Kuhle \& Pope, 2000). Recent studies have examined the influence of mutual fund fees on fund performance and have resulted in mixed findings. (Matallín-Sáez et al., 2016; Berk \& Van-Binsbergen, 2015; Chou \& Hardin III, 2013). Drago et al. (2010) also states that asset managers focus highly on the mutual funds' risk and return profile instead of focusing on the incentive fee in optimizing revenue stream. Mansor et al. (2015) has documented that there is 
no variance between the before-fee performance of equity funds in Malaysia. These findings were validated by Nanigian (2012), in which an insignificant relationship between fund fees and performance among funds with a minimum initial purchase requirement is found. Based on these findings, the following hypothesis is proposed:

H4: There is a relationship between mutual fund fee and mutual fund performance.

\subsection{Mediating Effect of Mutual Fund Fees}

According to Maiga (2015), firms should concentrate on intervening processes. Effective cost management strategies became a significant process in connecting information systems with profitability and performance. Piboonrungroj et al., (2011) proposes that there should be a mediator of transaction cost between inter-firm trust and business performance. The theory of performance supports cost-effectiveness as one of the attributes of high levels of performance. Therefore, the choice of mutual fund fees (cost) as a mediator is based on the theory of performance. Gil-bazo and Ruiz-verdú (2009) state that the negative association between fund fees and performance is strong and can be described as the result of fees and the existence of different degree of investor sensitivity towards historical performance. Therefore, it is essential to examine the relationship between fund performance and fees.

Ding and Wermers (2012) suggest that the quality of fund governance may have an influence on fund performance through lower fee negotiation with fund advisors. Berk and van Binsbergen (2015) conclude that skilful managers will secure greater rewards and better performance. Due to this, historical return, fund governance, timing and selection skills are hypothesized to have a direct effect on mutual fund fees and performance.

H5: Mutual fund fees mediate the relationship between the determinants and mutual fund performance.

\section{Conceptual Model}

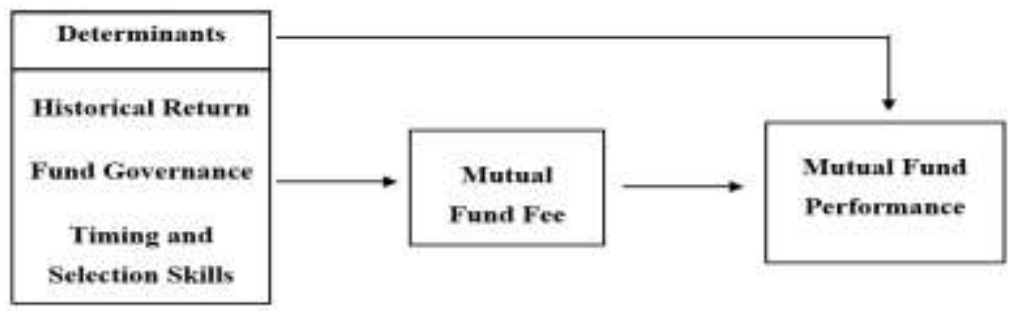

Figure 1: Conceptual Model

\section{Proposed Methodology}

This study integrates finance theories with the interdisciplinary theory of performance in explaining the effect of historical return, fund governance, timing and selection skills on mutual fund performance. A quantitative approach based on secondary data will be used in this study. This involves a correlational study, descriptive and hypothesis testing approach. The funds will be aggregated according to the type of mutual fund under examination. The data is gathered manually from the Morningstar database. The Morningstar database extraction is used for the availability of a classification system for mutual funds that will provide an effective comparison between funds in similar categories. This study will focus on Malaysian equity funds due to the high risk of equity compared to other types of mutual funds. This category is further expanded to include large and mid/small cap funds primarily investing in Malaysian companies. This sample will then be 
compared with a list of active mutual funds from the Malaysia Securities Commission. Multivariate regression analysis and structural equation modelling will be used to evaluate the association between the variables.

\section{Conclusion}

The study proposes a conceptual framework to test the effect of historical return, fund governance, timing and selection skills on mutual fund performance. The use of the theory of performance is the novel contribution of the study as it is has not previously been applied to the study of mutual funds. The mediating role of mutual fund fees is a further novel contribution of the study. The model fit will be confirmed after the collection of the research data and analysis. This study is important as it offers potential investors a better understanding of the charges and factors affecting the performance of mutual funds. Further, fund managers will be able to appropriately price their services and identify relevant factors that affect charges on fund performance. Future research may include other neighboring countries as the current study only considers mutual fund performance in Malaysia.

\section{References}

Abdullah, A. R. and Abdullah, N. A. (2015). Lipper's Rating and the Performance of Unit Trusts in Malaysia. Studies in Economics and Finance, 32(3), 322-339.

Adams, J. C., Mansi, S. A. and Nishikawa, T. (2010). Internal Governance Mechanisms and Operational Performance: Evidence From Index Mutual Funds. Review of Financial Studies, 23(3), 1261-1286.

Adams, J. C., Nishikawa, T. and Rao, R. P. (2016). Mutual Fund Performance, Management Teams and Boards. Journal of Banking and Finance, (303), 1-50.

Ahmad, K. M., Ashraf, S. and Ahmed, S. (2006). Testing Weak Form Efficiency for Indian Stock Markets. Economic and Political Weekly, 41(1), 49-56.

Berk, J. B. and Van Binsbergen, J. H. (2015). Measuring Skill in the Mutual Fund Industry. Journal of Financial Economics, 118(1), 1-20.

Casavecchia, L. (2016). Fund Managers' Herding and Mutual Fund Governance. International Journal of Managerial Finance, 12(3), 242-276.

Chen, Z. and J. Knez, P. (1996). Portfolio Performance Measurement: Theory and Applications. Review of Financial Studies, 9(2), 511-555.

Chevalier, J. and Ellison, G. (1997). Risk Taking by Mutual Funds as a Response to Incentives. Journal of Political Economy, 105(6), 1167-1200.

Chou, W. H. and Hardin, W. G. (2013). Performance Chasing, Fund Flows and Fund Size in Real Estate Mutual Funds. Journal of Real Estate Finance and Economics, 49(3), 379-412.

Cremers, M., Driessen, J., Maenhout, P. and Weinbaum, D. (2009). Does Skin in the Game Matter? Director Incentives and Governance in the Mutual Fund Industry. The Journal of Financial and Quantitative Analysis, 44(6), 1345-1373.

Dalmácio, F. Z. and Nossa, V. (2004). The Agency Theory Applied to the Investment. Brazilian Business Review, 1(1), 31-44.

Ding, B. and Wermers, R. (2012). Mutual Fund Performance and Governance Structure: The Role of Portfolio Managers and Boards of Directors (June 15, 2012).

Drago, D., Lazzari, V. and Navone, M. (2010). Mutual Fund Incentive Fees: Determinants and Effects. Financial Management, 39(1), 365-392.

Elger, D. (2007). Theory of Performance. Faculty Guidebook: A Comprehensive Tool for Improving Faculty Performance, University of Idaho, Pacific Crest, (4th ed), 11-14.

Fricke, E. (2013). Board Compensation, Holdings and Mutual Fund Expense Ratios. Managerial Finance, 39(3), 228250.

Gil-bazo, J. and Ruiz-verdú, P. (2009). The Relation Between Price and Performance in the Mutual Fund Industry. The Journal of Finance, 64(5), 2153-2183. 
Gil-bazo, J., Ruiz-verdú, P. and Santos, A. A. P. (2010). The Performance of Socially Responsible Mutual Funds: The Role of Fees and Management Companies, 94(2), 243-263.

Hornstein, A. S. and Hounsell, J. (2016). Managerial Investment in Mutual Funds: Determinants and Performance Implications. Journal of Economics and Business, 87, 18-34.

Hou, T. C.-T. (2012). Return Persistence and Investment Timing Decisions in Taiwanese Domestic Equity Mutual Funds. Managerial Finance, 38(9), 873-891.

Hu, M., Chao, C. C. and Lim, J. H. (2016). Another Explanation of the Mutual Fund Fee Puzzle. International Review of Economics and Finance, 42, 134-152.

Ippolito, R. A. (1989). Efficiency with Costly Information: A Study of Mutual Fund Performance, 1965-1984. The Quarterly Journal of Economics, 104(1), 1.

Jordan, B. D. and Riley, T. B. (2015). Volatility and Mutual Fund Manager Skill. Journal of Financial Economics, 118(2), 289-298.

Kuhle, J. L. and Pope, R. A. (2000). A Comprehensive Long-term Performance Analysis of Load vs. No-load Mutual Funds. Journal of Financial and Strategic Decisions, 13(2), 1-11.

Maiga, A. S. (2015). Information Systems Integration and Firm Profitability: Mediating Effect of Cost Management Strategy. Advances in Management Accounting, 25, 149-179.

Mansor, F., Bhatti, M. I. and Ariff, M. (2015). New Evidence on the Impact of Fees on Mutual Fund Performance of Two Types of Funds. Journal of International Financial Markets, Institutions and Money, 35, 102-115.

Matallín-Sáez, J.C., Soler-Domínguez A. and Tortosa-Ausina, E. (2016). On the Robustness of Persistence in Mutual Fund Performance. North American Journal of Economics and Finance, 36, 192-231.

Nanigian, D. (2012). Why Do Mutual Fund Expenses Matter? Financial Services Review, 21, $239-257$.

Phillips, B., Pukthuanthong, K., Raghavendra Rau, P., Brisley, N., Chen, J., Christoffersen, S., Rau, P. R. (2016). Past Performance May Be an Illusion: Performance, Flows, and Fees in Mutual Funds. Critical Finance Review, 5, 351-398.

Piboonrungroj, P., Disney, S.M. and Williams, S. J. (2011). Mediating Effect of Transaction Costs in Supply Chain Relationships: An Empirical Examination, British Academy of Management Annual Conference, 13, 1-9.

Rahman, S., Lee, C.-F. and Xiao, Y. (2016). The Investment Performance, Attributes, and Investment Behavior of Ethical Equity Mutual Funds in the US: An Empirical Investigation. Review of Quantitative Finance and Accounting.

Sharma, P. and Paul, S. (2015). Testing the Skill of Mutual Fund Managers: Evidence from India. Managerial Finance, 41(8), 806-824.

Williamson, O. E. (1981). The Economics of Organization: The Transaction Cost Approach. American Journal of Sociology. 